\title{
An Historical Perspective of Reward Systems: Lessons Learned from the Scientific Management Era
}

\author{
Helene L. Caudill, Ph.D. (Corresponding Author) \\ Dean, New College, St. Edward's University, 3001 South Congress Ave. \\ Austin, Texas 78704, United States \\ Email: helenec@stedwards.edu \\ Constance D. Porter, Ph.D. \\ Associate Professor, Bill Munday School of Business, St. Edward's University \\ 3001 South Congress Ave. \\ Austin, Texas 78704, United States \\ Email: constanp@stedwards.edu
}

Doi:10.5296/ijhrs.v4i4.6605

URL: http://dx.doi.org/10.5296/ijhrs.v4i4.6605

\begin{abstract}
This paper reveals how similar the reward systems prevalent during the scientific management era are to the rewards systems in use today. Systems popular today, such as profit sharing, gain sharing, skill/knowledge-based pay, merit-based pay/pay for performance, and variable-based pay, were also advocated during the reign of scientific management. The ideas expressed by several key scientific management contributors, including Frederick W. Taylor, Henry L. Gantt, Harrington Emerson, and Frank B and Lillian M. Gilbreth, are detailed. These ideas are compared and contrasted with existing reward systems and their underlying premises. In addition, the lessons learned from the scientific management era as they relate to reward system philosophies of today are presented.
\end{abstract}

Keywords: Workplace Rewards, Strategic Compensation Management, Incentive Systems, Pay Systems, Scientific Management Era

\section{Introduction}

A common theme of strategic compensation management is that rewards play a key role in fulfilling an organization's mission and in aligning the interests of labor and management (Larkin, Pierce, \& Gino, 2014; Moriarty, 2014). To achieve these shared interests, domestic and global companies continue to experiment with a variety of reward systems (Aamir, Jehanzeb, Rasheed \& Malik, 2012; Khan, Aslam, \& Lodhi, 2011). Preexisting systems, such as profit sharing and gain sharing, as well as so-called new systems, such as skill/knowledge-based pay, merit-based/pay for performance, and value-based pay are the topics of much anecdotal, conceptual and empirical literature (Larkin et al., 2014; Miller, 
2014a; Miller, 2014b; Xavier, 2014).

The basic premise of reward systems is to maintain employee motivation in order to increase production and sustain a competitive edge, while keeping costs low (Kanin-Lovers \& Porter, 1991; Milkovich, Newman \& Gerhart, 2011). This basic premise of reward systems has been evident throughout the centuries but was especially dominant during the historical period spanning the late 1800 s to the early 1920 s, a period known as the scientific management era (Wren, 1987a). Thus, a review of the reward systems used and advocated during this time period will help in understanding how and why systems of today have evolved. Additionally, this analysis will reveal which reward systems advocated during the scientific management era are still valid and valuable within the context of current reward system knowledge.

The main purpose of this paper, then, is to take an historical perspective of reward systems in order to better understand the present and not just the past (Lawrence, 1984). And although Lawrence (1984) advocates "the study of a subject in light of its earliest phases and subsequent evolution" (p. 307), a more narrow focus will be taken here in looking specifically at the scientific management era. This era was chosen because of its overall significance to the evolution of management thought (Duncan, 1989; Wren, 1987a).

The significance of the scientific management era to the field of management in general, and to the field of compensation management, in particular, will be discussed first. As part of this discussion, the ideas expressed by several key contributors, including Frederick W. Taylor, Henry L. Gantt, Harrington Emerson, and Frank B and Lillian M. Gilbreth, will be detailed. These ideas will then be compared and contrasted with existing reward systems and their underlying premises. Lastly, the lessons learned from the scientific management era as they relate to reward system philosophies of today will be presented. As a matter of clarification, rewards systems will be used in a generic sense to mean incentive systems, pay systems, and compensation systems; therefore, these terms are used interchangeably throughout the paper.

\section{Reward Systems Advocated During the Scientific Management Era}

The scientific management era is ripe with offerings of management principles and philosophies that are still prevalent today. Frederick (1963) even credits this era with providing a first approximation of the meaning of management. This meaning was characterized by a search for efficiency and systematization. In particular, the use of reward systems played an integral part in the successful implementation of the philosophy of scientific management. Drury (1915) notes that when the American Society of Mechanical Engineers (ASME) first promoted the art of management they were not interested equally in all of management's different aspects. The problem which they considered almost exclusively was termed the "wage problem" (Drury, 1915: 32). Further, Taylor's paper titled, "A Piece-Rate System: A Step Toward Partial Solution of the Labor Problem," presented to the ASME in 1895, was the first formal presentation of a system of management which he had devised and which was later called "scientific management" (Merkle, 1980). 
Despite this seemingly important role that reward systems played during the scientific management era, few writers have stressed their importance specifically. Instead, articles abound of those criticizing and defending Taylor's philosophies (Fry, 1976; Locke, 1982; Wrege \& Perroni, 1974), as well as narratives about Taylor's life (Feiss, 1924; Copely, 1969). Other writers have focused on Taylor's and his disciples' implementation of scientific management (Nadworny, 1957; Nelson \& Campbell, 1972; Petersen, 1986; Petersen, 1989), while others have described the advent of scientific management in international contexts (Daito, 1972; Rowlinson, 1988; Sasaki, 1992; Sheldon, 1925; Wren, 1980). An exception to this literature described is an analysis by Peach and Wren (1992) who trace "the evolution of pay for performance from antiquity through the 1950s, viewing it from the perspective of four overlapping eras" (p. 6). Although one of the time periods included in their article is the scientific management era, only a brief overview of the reward systems prevalent during that time is described.

Thus, in order to gain a deeper understanding of the reward systems prevalent during the scientific management era five key contributors will be presented: (1) Frederick W. Taylor (2) Henry L. Gantt, (3) Harrington Emerson, (4) Frank B. Gilbreth, and (5) Lillian M. Gilbreth. These five contributors were well known during this era, and actually, as Nadworny (1957) explains, "The label 'scientific management' is the one with which we are most familiar today, but in 1915, and earlier, management programs were most likely to be identified with the names of the management engineers themselves, e.g., 'Taylor system,' 'Gantt system,' 'Emerson system,' and so forth" (p. 23). By viewing these writers individually and collectively, a more thorough and careful analysis of reward systems can be presented. Although much information about reward systems can be found in these writers' works, the largest and most relevant material can be found in the writings of Frederick W. Taylor.

\subsection{Frederick W. Taylor}

During Taylor's testimony before the Special House Committee concerning various aspects of his scientific management philosophy, he defined what scientific management is not by stating, among other characteristics, that "it is not a new scheme of paying men; it is not a piecework system; it is not a bonus system; it is not a premium system; it is no scheme for paying men" (Taylor, 1947: 26). Additionally, he noted that "under scientific management, the particular pay system which is adopted is merely one of the subordinate elements" (1911: 34). However, he also contended that the task and the bonus constituted "two of the most important elements of the mechanisms of scientific management" (1911:122). The latter of these three statements seems to be the most representative of Taylor's true thoughts concerning reward systems. A significant portion of his book Shop Management is actually devoted to the subject of wage incentive plans. In particular, he discussed the need for these plans to offer high wages to the worker and low labor costs to the employer, and to promote individual pay for performance. He proposed his own payment system, the differential piece -rate plan, as the best choice for attaining the "one best way." 


\subsubsection{High Wages/Low Labor Cost}

One of Taylor's main goals in advocating the philosophy of scientific management was to ensure a mutuality of interests between employee and employer. He believed that one of the keys to forging this relationship was to understand the basic premise of how to motivate these individuals. This premise relates to Taylor's belief that what "the workmen want from their employers beyond anything else is high wages, and what employers want from their workers most of all is a low labor cost of manufacture" (1903: 22). Indeed, Taylor did hold strong views that workers would not increase their productivity "unless assured a good liberal increase, which must be permanent" (1903: 26).

However, this belief of man as a total economic being motivated by money alone has prompted much criticism (Fry, 1976). Nelson and Campbell (1972) provide an explanation for Taylor's concept of money and motivation by noting that "Taylor was first of all an engineer, and his technical outlook apparently accounted for his simplistic view of human nature, particularly his beliefs that workmen desired only higher wages and that other benefits were demeaning and unmanly" (p. 4). Nevertheless, Taylor's book, Shop Management, was "written with the object of advocating high wages and low labor costs as the foundation of the best management" (1903: 22).

\subsubsection{Individual Pay for Performance}

Another common theme throughout the writings of the scientific management era centered on individual pay for performance. Merkle (1980) asserts that Taylor's differential piece-rate system was:

The first plan to stress individualism, to discard utopian ideas such as profit-sharing, to appeal directly to individual desire for higher wages in a way expressly designed to break up "groups, combinations, and classification" of workers leading to "soldiering" and trade unionism, and to do this by a process which was "scientifically" based on records of labor productivity, thus eliminating the "guesswork" in rate-setting on the part of management (p. 7).

Taylor's main reason for promoting individual, as opposed to group or cooperative, rewards was his belief that "personal ambition always has been and will remain a more powerful incentive to exertion that a desire for the general welfare" (1903: 95; 1911: 37). This individual ambition was just one of Taylor's reasons for criticizing cooperative systems. He also blamed their ineffectiveness on the remoteness of the rewards, the lack of worker control in attaining the reward, and the increase in soldiering, or slacking off, such systems tended to promote.

In terms of the remoteness of the reward, Taylor believed wages could only be effective in motivating workers to excel if they came soon after the work was completed. He noted that "the average workman cannot look forward to a profit which is six months or a year away" (1903: 37). In terms of worker control, Taylor understood that in many cases, it was "neither 
right nor just that they should share either the profits or the losses, since those may be due to in great part to causes entirely beyond their influence or control, and to which they do not contribute" (1911: 95). But Taylor's harshest criticism about cooperative systems concerned with the few misplaced "drones" who did not produce but were free to share in the profits with the group. Additionally, Taylor felt that "gang work almost inevitably results in a falling off in earnings and consequent dissatisfaction" (1903: 53).

The most prevalent cooperative payment system during the scientific management era, as well as during the systematic management movement that preceded and greatly influenced this era, was profit sharing (Litterer, 1963). While profit sharing and gain sharing are both based on group incentives, gain sharing is based on cost savings as opposed to profit increases (Milkovich et al., 2011). It was Henry Towne who, as president of the ASME in 1889, presented the first paper to the society under the title, "Gain-Sharing" (Drury, 1915). Towne's plan ensured workers a guaranteed wage rate, or "gain," plus an even split of the cost savings between the workers and management (Wren, 1987a). As with profit sharing, Taylor (1911) was also not impressed with gain sharing by contending that "while workmen are always ready to share the profits, they are neither able nor willing to share the losses" ( $\mathrm{p}$. 95).

Nevertheless, Towne's gain sharing system prompted other new payment schemes to emerge, most notably, Frederick Halsey's premium plan. It was in 1891 that Halsey presented his paper titled, "The Premium Plan of Paying for Labor" before the ASME. With the Halsey plan, workers received a guaranteed day rate, plus a premium rate based on time saved which was derived from past production records (Drury, 1915; Wren, 1987a).

Taylor referred to the Towne and Halsey plans as one, calling it the Towne-Halsey Plan, noting that Mr. Halsey had simply improved upon the plan originated by Mr. Towne (Taylor, 1903). The common element in both plans was the sharing of gains between management and workers (Peach \& Wren, 1992). While Taylor approved of the Towne-Halsey plan's use of a standard time to calculate incentives, he felt that the plan still did not promote the true meaning of the scientific management philosophy (Taylor, 1903, 1911). Taylor, therefore, devised his own plan called the differential piece-rate system.

\subsubsection{Differential Piece-Rate System}

As Taylor's remedy to the Towne-Halsey plan and other cooperative reward systems, he proposed a differential piece-rate system. This system greatly rewarded workers who attained the standard, while giving a much lower pay to those who did not meet the standard (Wren, 1987a). The high rate was set so that the average employee who met the standard could earn 125 percent of the standard base pay; the low rate was set at 90 percent of the base (Peach \& Wren, 1992).

Taylor (1903) noted that the one feature that his plan had in common with the Towne-Halsey plan was that if compensated fairly, employees would be motivated to work harder and to be more productive. However, the two plans had several major differences. One difference 
centered on who controlled how the work was accomplished. Taylor's plan emphasized the need for management to have this control, while the Towne-Halsey plan encouraged the workers to devise their own means to determine their tasks and speed. Another major difference between the two plans was in how the standard was determined. The Towne-Halsey plan used an historical base while Taylor's plan emphasized a scientific study of unit times.

The use of time study also distinguished Taylor's differential piece-rate system with straight piece-rate systems as well as with day-rate systems. According to Taylor, straight piece-rate systems encouraged systematic soldiering because employers arbitrarily cut rates that, in turn, caused workers to reduce their output. Taylor also believed that a uniform standard rate of pay per day encouraged workers to "take it easy" and, thus, "under this plan the better man gradually but surely slow down their gait to that of the poorest and least efficient" (1903: 31).

Despite flaws with these payment plans, Taylor saw a need to use a contingency approach to reward systems. He explained that "each of these systems has its own special conditions under which it is to be preferred to either of the other" (1903: 71). In particular, he praised the use of Henry L. Gantt's task work with a bonus system.

\subsection{Henry L. Gantt}

Although Henry L. Gantt is most famous for the development of the Gantt chart used for project management, he also received notoriety during the scientific management era for his task work with a bonus system of compensation management (Petersen, 1986). Like Taylor, Gantt also saw the need to ensure the mutuality of interests between labor and management. Gantt (1919) believed that one key way to promote this relationship was through cooperation and he stated that "we must secure the confidence and co-operation of the workmen by assuring him equitable compensation" (p. 110). Gantt's task work with a bonus plan was his answer to offering an equitable reward system. This system differed in many ways from Taylor's differential piece-rate system, and as Duncan noted "Gantt agreed with almost all of Taylor's ideas except for his system for rewarding labor” (1989: 58).

In actuality, it is more likely that Gantt did not completely disagree with Taylor's system, but simply saw his own as being more "in accord with human nature" (Gantt, 1919: 123). Whereas Taylor emphasized the need for management to be in control of the work, Gantt understood that workers "prefer to work by the day and be themselves the judges of the amount of work they shall do in that day" (Gantt, 1919: 107).

Because it often took years to scientifically study all tasks, Gantt's plan was introduced prior to Taylor's at the Bethlehem Steel Company where many scientific management principles were implemented. Gantt's plan was an interim system that used the basics of Taylor's differential piece-rate system along with additional pay. Taylor also described Gantt's plan as a bridge between the "slow pace of ordinary day work," to "the high speed" of his new differential piece-rate system (1903: 77). 
The specifics of Gantt's plan first included paying a fixed bonus for performing the task within the standard time. Gantt later saw this fixed bonus as a flaw of the system because it limited the incentive for workers to produce more once they had earned their bonus. To remedy this situation, he added an incentive based on paying the workers for the time allowed, plus a percentage of that time if they completed the job within the standard time or less (Wren, 1987a). Thus, a worker who completed a four-hour job in less time would still receive four hours of pay.

Another feature of Gantt's plan was paying the foreman a bonus for each worker who made the bonus, as well as an additional bonus if all workers under them made the bonus. Gantt (1919) was extremely proud of this feature and noted that "this is the first recorded attempt to make it to the financial interest of the foreman to teach the individual worker, and the importance of it cannot be overestimated, for it changes the foreman from a driver of his men to their friend and helper" (p. 115).

In summary, Gantt's plan was mainly concerned with efficiency. He strongly advocated that workers should not receive increases in wages over the day rate unless they maintained a certain degree of efficiency. Despite Gantt's belief that management knew it was "a well-recognized fact that the efficient man at high wages is much more profitable to his employer than the inefficient man at low wages," he felt that management did not give enough consideration to increasing their workers' efficiency levels (1919: 97). Another contributor during the scientific management era who was keenly focused on efficiency was Harrington Emerson.

\subsection{Harrington Emerson}

In Harrington Emerson's book, The Twelve Principles of Efficiency, he placed the efficiency reward last. This placement may have been due, in part, to his firm belief that "no other subject is so disturbing as wages or requires so much of the "fair deal'" (Emerson, 1917: 188). Although he approved of Taylor's differential piece-rate system and Gantt's task work with a bonus system and their emphasis on establishing a standard time for each task, Emerson felt the worker needed more flexibility in being able to receive a bonus. Thus, he "found it undesirable to make the line of demarcation so sharp between efficiency and inefficiency" (1917: 360).

Based on this need for flexibility, Emerson established a bonus system which grouped efficiency ranges and equated a percent bonus for each range. Accordingly, a worker would receive a bonus for simply reaching the 100 percent efficiency level and an additional bonus above this level based on actual time saved (Peach \& Wren, 1992; Wren 1987a). In addition to Emerson's contribution of devising a unique incentive plan, he also advocated market pricing and non-monetary rewards, as well as the importance of basing wages on both quantity and quality. 
Emerson agreed with the concept of market pricing which involves setting pay structures based on rates paid in the external market (Milkovich et al., 2011). He asserted that "the worker cannot be expected to work for an employer for less pay than is paid under similar conditions for the same class of work by another employer," and "the wage payer cannot be asked to pay higher wages than the current rate" (1917: 188). In terms of non-monetary rewards, Emerson noted that his efficiency reward was not simply a money payment. Further, he explained that "men have been willing to die for a smile" (1917: 365). The importance of basing wages on both quantity and quality stemmed from his philosophy of his efficiency reward that required accurate measurement of work based on these two elements. In addition to Harrington Emerson's original contributions, Frank and Lillian Gilbreth also contributed several unique and relevant ideas concerning reward systems that are still valid today.

\subsection{Frank and Lillian Gilbreth}

The husband and wife team of Frank and Lillian Gilbreth wrote collectively (Gilbreth \& Gilbreth, 1919) and as individual authors (F. B, Gilbreth, 1911, 1914; L. M. Gilbreth, 1919). But their ideas are most often described in unison. This consensus of their ideas is best presented in their book titled, The Writing of the Gilbreths, which includes their most significant contributions (Spriegal \& Myers, 1953). The Glibreths' ideas concerning reward systems still hold special relevance today. This relevance is noted by Brass, a reviewer of their classic writings when he stated that "I was particularly impressed by the similarity of the Gilbreths' discussion of incentives to many modern day textbook chapters in reward systems" (1986: 450). It is actually Lillian's book, The Psychology of Management, and Frank's book, Primer of Scientific Management, in which the majority of the Gilbreths' thoughts concerning rewards systems are presented.

Lillian (1919) intuitively noted that there are two kinds of incentives, direct incentives which include ambition and pride of the worker, and indirect incentives which include rewards and punishment. She assuredly stated that "there can be no doubt that a reward is an incentive" (p. 273) and that "punishment is just as surely an incentive to action as is reward" (p. 274). Although she did not advocate the use of punishment over reward, she did believe that punishment could motivate the worker to do better if it was a "scientifically prescribed punishment" (p. 274).

More specifically, Lillian (1919) described the characteristics of rewards under scientific management. These characteristics explained that reward systems should be (1) positive in terms of their perceived gain to the worker; (2) predetermined, meaning that they should be decided upon prior to the start of a job; (3) personal/individual designed "for that particular man for that particular work;" (4) fixed/unchanged so that once the rate is established it must not be cut; (5) assured by the organization so that employees trust that "rewards have always been paid in the past, therefore probably will be in the future;" and (6) prompt so that the reward is announced and received as soon as the work has been done (p. 281).

Interestingly, Lillian (1919) noted that "probably the greatest incentive, next to promotion 
and more pay, are shorter hours and holidays (p. 303). In terms of promotion, Lillian and Frank advocated their three position plan of promotion which encouraged teaching and skill development (Gilbreth \& Gilbreth, 1919). Taylor also advocated the promotion of workers. He stated that "it will prove a wise policy to promote such men to better positions and pay, when they have shown themselves capable of accomplishing results and the opportunity offers" (Taylor, 1903: 142).

Besides sharing common views about promotion, Taylor and the Gilbreths shared many other beliefs, particularly, the importance of time study. But after Frank was denied admission into Taylor's inner circle, he and Lillian took a strong stance to clarify that motion study was not the same as time study and denounced the developers and practitioners of time study for failing to acknowledge the value of motion study (Nadworthy, 1957). Despite this apparent conflict over time and motion studies, the Gilbreths were avid supporters of Taylor and scientific management.

In support of scientific management, the Gilbreths reviewed the strengths and weaknesses of many reward systems, including profit sharing, gain sharing, day rate, Halsey's premium plan, Gantt's task with a bonus plan, and Taylor's differential piece-rate system (Gilbreth, 1914; Glibreth, 1919). They agreed with Taylor about the inequities of cooperative systems and the need for careful task analysis and time studies, concluding that Taylor's method was the very best method of compensating employees (Gilbreth, 1914) and the "ultimate form of compensation" (Gilbreth, 1919: 298). This enthusiastic recommendation for Taylor's reward system came despite that fact that it was "much admired but rarely applied" (Jenks, 1960: 442). Frank Gilbreth even chose Taylor's system over his own system that consisted of three rates: (1) a day or flat minimum for all workers new to the job; (2) a middle rate for those who met compliance standards based on prescribed motions; and (3) a high rate for those who not only met compliance standards, but who also met the prescribed time and quality and quality standards.

In summary, the reward systems prevalent during the scientific management era have a number of similarities and many scholars claim that it is difficult to clearly distinguish among the variations (Peach \& Wren, 1992). Yoder (1948) notes that “... all the many plans are similar in a number of features. The name of their designer, generally attached to them, frequently appears as the biggest single difference" (p. 398). Indeed, it is also sometimes difficult to distinguish among the variations of the reward systems in existence today.

\section{Reward Systems in Existence Today}

In several recent articles focusing on strategic compensation management, common themes emerge, including establishing pay structures to attract and retain top performers, establishing pay equity, and developing clearly articulated pay for performance systems (Downes \& Choi, 2014; Gupta \& Shaw, 2014; Larkin et al., 2012). These same themes were also espoused by Taylor, Gantt, Emerson, and the Gilbreths a century ago. What is new today are mainly the 
names given to these reward systems, such as skill/knowledge-based pay, merit-based pay/pay for performance, and variable-based pay. In reality, are these plans actually new or recent, or are their underlying premises different than those advocated and implemented during the scientific management era? A closer look at each will help us realize that the founding premise of reward systems, which focuses on motivating employees to improve and be more productive, has stood the test to time.

\subsection{Skill/Knowledge-Based Pay}

Skill/knowledge-based pay, and its close derivatives called competency-based pay and values-based pay, is an individual incentive system that rewards employees for skills, knowledge, and competencies, as opposed to the positions they hold (Moriarty, 2014; Snell \& Bohlander, 2013). A key benefit of this pay scheme is that it encourages continuous learning and allows employees to increase their pay, even when promotions are not available. Contributors during the scientific management era also advocated individual incentives and the need to encourage workers to become "first-class men" in order to perform tasks in the most efficient way (Taylor, 1911; Gilbreth, 1914). In particular, Taylor denounced systems that paid workers "according to the position they fill, and not according to their individual character, energy, skill, and reliability" (Drury, 1915: 33). Further, the notion behind values-based pay is that employees with better skills and knowledge are able to the do the same quality work in less time, and therefore, should be paid accordingly (Milkovich et al., 2011; Solano, 1992). This efficiency view of pay was clearly evident in the writings of Emerson and Gantt whose reward systems paid bonuses based on the amount of time saved above and beyond the predetermined standard.

\subsection{Merit-Based Pay/Pay for Performance}

Merit-based pay systems that reward employees for their individual and oftentimes, group performance, have their roots in equity theory. A central tenet of equity theory asserts that employees' perceived contributions should be rewarded equitably in comparison to other employees' contributions. Thus, if employees perceive that they are not being rewarded fairly, they may reduce their output and lower their commitment to the organization (Adams, 1965). Organizations must then balance the need to reward top performers without alienating the remaining workforce (Downes \& Choi, 2014; Miller, 2014a).

Taylor and most of his scientific management colleagues were not specifically concerned about the psychological impact of paying top performers above and beyond those of the average employee. Larkin et al. (2014) advocate that pay based on individual performance encourages employers to work harder and if work can be easily counted, then individual merit is more likely to be successful than using a flat or hourly-based pay. And while profit sharing and gain sharing plans are still popular today, these types of plans were often criticized during the scientific management era. Indeed, Taylor (1903) argued that these plans encouraged mediocrity because of "drones" who did not produce, but shared in the profits or gains regardless of their input. In today's terminology, "drones" are called "free-riders" and there is still concern that these workers have a negative influence on limiting the productivity 
of others (Larkin et al., 2014).

\subsection{Variable-Based Pay}

Variable-based pay, which includes the use of bonuses, stipends, and other forms of incentivized rewards, offer organizations more flexibility in implementing their compensation strategies in comparison to fixed-based pay programs (Milkovich et al., 2011). In particular, during volatile economic times, the use of variable pay allows a company to reward individuals and teams based on current profits and productivity, without the promise or expectation that such rewards will be offered continuously. According to Snell and Bohlander (2013), more than 80 percent of global companies utilize variable-based pay in some form. In the United States, where individualized pay is highly promoted, 91 percent of companies offer a variable pay plan (Miller, 2014b). Thus, Taylor and Gantt, who both strongly recommended employee bonuses, would likely not be surprised to see that the use of variable pay as an employee motivator is a popular and common compensation strategy today.

\section{Lessons Learned from the Scientific Management Era}

A comparison of reward systems popular today with those of the scientific management era reveals that strategies recommended a century ago still have reverence and meaning today. Wren (1987b) offers a number of reasons why it is important to study the history of management, one of which is history's ability to "provide a framework for building and integrating knowledge" (p. 342). This paper provides such a framework in relation to reward systems. By reviewing the ideas from key contributors of the scientific management era, we know have a clearer understanding of reward systems in use today. In turn, a number of lessons from this historical period are offered. These seven lessons are certainly not all inclusive, but do integrate the major premises related to reward systems prevalent at that time, which are still prevalent and viable today.

\subsection{Lesson One: Reward systems should link individual pay with performance.}

The individual employee is an important and critical contributor to an organization's effectiveness. The use of individual, as opposed to group or cooperative incentives, is likely the most fair and equitable way to compensate employees. Additionally, individual incentives focus on the person and not strictly the position held.

\subsection{Lesson Two: Reward systems should reflect the situation at hand.}

A contingency-based reward system will ensure that the right pay mechanisms are used for the particular work being performed. For example, if an employee's job is to greet customers, this employee should be paid by the hour or day, not by the number of customers greeted.

\subsection{Lesson Three: Reward systems should promote increased productivity and efficiency without sacrificing quality.}


Increased output, coupled with high quality, will help an organization remain competitive. In theory, this will then provide employees with high wages and employers with lower labor costs.

\subsection{Lesson Four: Reward systems do impact labor-management relations.}

Management has a right to demand a high level of performance from their employees, but only if they offer fair and equitable wages in return. Moreover, management must ensure that the workforce has the proper skills, training, and resources for the work to be done in the most efficient and effective way possible.

4.5 Lesson Five: Reward systems should be accepted and understood by employees.

In order to reduce free-riding, the reward system must be fully explained and understood by the employees. A clear communication plan will help to ensure that the employees will accept the system so that they will produce at their highest levels without fear of reprisal.

\subsection{Lesson Six: Reward systems should be timely.}

The timing of the reward helps link pay with performance. This, in turn, helps motivate employees to continue to improve. In particular, bonuses should be paid as soon as possible after the work has been completed.

4.7 Lesson Seven: Reward systems should be designed with the notion that money is a motivator.

Although there is still controversy over the ability of money to motivate, the saying that "people work to live" rather that "people live to work" makes intuitive sense. How powerfully money can motivate is still questionable, but it is necessary to consider the impact money has when contemplating any reward system.

These seven lessons are not only evident in the writings of Taylor, Gantt, Emerson, and the Gilbreths, but also in the current compensation management literature as well. And though we tend to think of today's circumstances as being unique, there are often patterns that appear from one time period to the next. "Mark Twain once said that history doesn't repeat itself but sometimes it rhymes" (Kantrow, 1986: 83). Reward systems of the scientific management era certainly "rhyme" with those of today. And now that we have a better understanding of the past we will have better insight into shaping the present, as well as the future.

\section{References}

Aamir, A., Jehanzeb, K., Rasheed, A., \& Malik, O. M. (2012). Compensation methods and employees' motivation (with reference to employees of National Commercial Bank Riyadh). International Journal of Human Resource Studies, 2(3): 221-230.

Adams, J. S. (1965). Inequity in social exchange. In Advances in Experimental Social 
Psychology: 267-299. Berkowitz L (ed). New York: Academic Press.

Brass, D. J. (1986). Special book review section of the classics of management: A review of the writings of the Gilbreths. Academy of Management Journal, 14 (2): 448-451.

Copely, F. B. (1969). Frederick W. Taylor: Father of scientific management. New York: Augustus M. Kelley.

Daito, E. (1972). Railways and scientific management in Japan 1907-1930. Business History Review, 46(1): 1-44.

Downes, P. E., \& Choi, D. (2014). Employee reactions to pay dispersion: A typology of existing research. Human Resource Management Review, 24: 53-66.

Drury, H. B. (1915). Scientific management: A history and criticism. New York: Columbia University.

Duncan, W. J. (1989). Great ideas in management. San Francisco: Josey-Bass Publishers.

Emerson, H. (1914). Efficiency as the basis for operation and wages $\left(3^{\text {rd }}\right.$ ed.). New York: The Engineering Magazine Company.

Emerson, H. (1917). The twelve principles of efficiency $\left(5^{\text {th }}\right.$ ed.). New York: The Engineering Magazine Company.

Feiss, R. A. (1924). The life of Frederick W. Taylor: A review. Harvard Business Review, 3(1): 85-88.

Frederick, W. C. (1963). The next development in management science: A general theory. Academy of Management Journal, 6(3): 212-219.

Fry, L. W. (1976). The maligned F.W. Taylor: A reply to his many critics. Academy of Management Review, 1(3): 124-129.

Gantt, H. L. (1919). Work, wages, and profits ( $2^{\text {nd }}$ ed.). New York: The Engineering Magazine Company.

Gilbreth, F. B. (1911). Applied motion study. New York: D. Van Norstrand Company.

Gilbreth, F. B. (1914). Primer of scientific management. New York: D. Van Norstrand Company.

Gilbreth, F. B., \& Gilbreth, L. M. (1917). Applied motion study: A collection of papers on the efficient method to industrialized preparedness. New York: Sturgis and Walton Co. 
Gilbreth, L. M. (1919). The psychology of management. New York: The Macmillan Company.

Gupta, N., \& Shaw, J. D. (2014). Employee compensation: The neglected area of HRM research. Human Resource Management Review, 24: 1-4.

Jenks, L. H. (1960). Early phases of the management movement. Administrative Science Quarterly, 5 (3): 421-447.

Kanin-Lovers, J., \& Porter, A. (1991). Skill-based pay as a management system. Journal of Compensation and Benefits, 7(1): 50-52.

Kantrow, A. M. (ed.) (1986, January/February). Why history matters to managers. Harvard Business Review, 81-88.

Khan, R. I., Aslam, H. D., \& Lodhi, I. (2011). Compensation management: A strategic conduit towards achieving employee retention and job satisfaction in banking sector of Pakistan. International Journal of Human Resource Studies, 1(1): 89-97.

Larkin, I., Pierce, L., \& Gino, F. (2012). The psychological costs of pay-for-performance: Implications for the strategic compensation of employees. Strategic Management Journal, 33: 1194-1214.

Lawrence, B. S. (1984). Historical perspective: Using the past to study the present. Academy of Management Review, 9(2): 307-312.

Litterer, J. A. (1963). Systematic management: Design for organizational recoupling in American manufacturing firms. Business History Review, 37(4): 369-391.

Locke, E. A. (1982) The ideas of Frederick W. Taylor: An evaluation. Academy of Management Review, 7(1): 14-24.

Merkle, J. A. (1980). Management and ideology: The legacy of the international scientific management movement. Berkeley: University of California Press.

Milkovich, G. T., Newman, J. M., \& Gerhart, B. (2011). Compensation, $10^{\text {th }}$ ed. New York: McGraw-Hill.

Miller, S. (2014a, August 12). Pay raises focus on rewarding top performers. Society for Human Resource Management. Retrieved from http://www.shrm.org/hrdisciplines/compensation/articles/pages/pay-raises-2015.aspx. 
Miller, S. (2014b, September 2). Variable pay spending spikes to record high. Society for Human Resource Management. Retrieved from http://www.shrm.org/hrdisciplines/compensation/articles/pages/variable-pay-high.asp $\mathrm{x}$.

Moriarty, J. (2014). Compensation ethics and organizational commitment. Business Ethics Quarterly, 24 (1): 31-53.

Nadworny, M. J. (1957). Frederick Taylor and Frank Gilbreth: Competition in scientific management. Business History Review, 31(1): 23-34.

Nelson, D., \& Campbell, S. (1972). Taylorism versus welfare work in American industry: H. L. Gantt and the Bancrofts. Business History Review, 46(1):1-16.

Peach, E. B., \& Wren, D. A. (1992). Pay for performance from antiquity to the 1950s. Journal of Organizational Behavior and Management, 7(4): 5-26.

Peterson, P. B. (1986). Correspondence from Henry L. Gantt to an old friend reveals new information about Gantt. Journal of Management, 12(3): 339-350.

Peterson, P. B. (1989). The pioneering efforts of Major General William Crozier (1855-1942) in the field of management. Journal of Management, 15(3): 503-516.

Rowlinson, M. (1988) The early application of scientific management by Cadbury. Business History, 30(4): 377-395.

Sasaki, S. (1992). The introduction of scientific management by the Mitsubishi Electric Engineering Co. and the formation of an organized scientific management movement in Japan in the 1920s and 1930s. Business History, 34(2): 12-27.

Sheldon, O. (1925). The development of scientific management in England. Harvard Business Review, 3(2): 129-140.

Snell, S., \& Bohlander, G. (2013). Managing Human Resources, $10^{\text {th }}$ ed. Mason, OH: South-Western Cengage Learning.

Solano, M. S. (1992). Making pay for performance work in the 1990s. Journal of Compensation and Benefits, 8(5): 24-31.

Spriegal, W. R., \& Myers C. E. (eds.) (1953). The writings of the Gilbreths. Homewood, IL: Irwin.

Taylor, F. W. (1947) Scientific management comprising Shop management (1903), The 
principles of scientific management (1911), Testimony before the special house committee (1912). New York: Harper \& Brothers Publishers.

Wrege, C. D., \& Stoka, A. M. (1978). Cooke creates a classic: The story behind F. W. Taylor's principles of scientific management. Academy of Management Review, 3(2): 736-749.

Wrege, C. D., \& Perroni, A. G. (1974). Taylor's pig-tale: A historical analysis of Frederick W. Taylor's pig-iron experiments. Academy of Management Journal, 17(1): 6-27.

Wren, D. A. (1987a). The evolution of management thought ( $3^{\text {rd }}$ ed.) New York: John Wiley and Sons.

Wren, D. A. (1987b). Management history: Issues and ideas for teaching and research. Journal of Management, 13(2): 339-350.

Wren, D. A. (1980). Scientific management in the U.S.S.R., with particular reference to the contribution of Walter N. Polakov. Academy of Management Review, 5(1): 1-11.

Yoder, D. (1948). Personnel management and industrial relations ( $3^{\text {rd }}$ ed.) New York: Prentice-Hall.

Xavier, B. (2014). Shaping the future research agenda for compensation and benefits management: Some thoughts based on a stakeholder inquiry. Human Resource Management Review, 24: 31-40. 